\title{
THE NON-ALIGNED MOVEMENT AT THE CROSS- ROADS-THE JAKARTA SUMMIT ADAPTING TO THE POST-COLD WAR ERA.
}

\section{J.J.G. Syatauw*}

\section{INTRODUCTION}

The 10th Conference of Heads of State or Government of Non-Aligned Countries which convened in Jakarta from 1-6 September 1992, known as the "Jakarta Summit", began under rather difficult conditions. In the three years which followed the Belgrade Summit of September 1989, the post-Cold War world had not yet settled down. The disturbing effect of the disintegration of the Communist bloc in Eastern Europe was still being experienced in the world at large. As the Eastern European drama unfolded, the Middle East came to the boil when Iraq threatened Saudi Arabia and subsequently invaded Kuwait. A number of Arab non-aligned countries became involved in a conflict that the Non-Aligned Movement (hereinafter referred to as "the NAM" or "the Movement") itself could not solve.

The situation for the NAM worsened still when the Balkans were caught in a new wave of political unrest which saw the Federal Socialist Republic of Yugoslavia, which at that time held the chair of the NAM, slowly disintegrate. Yugoslavia had held the chair of the Movement since the 9th Non-Aligned Conference in Belgrade in 1989. In that capacity and as a Balkan State herself, Yugoslavia had every opportunity to use her influential position and her own leadership qualities to guide the NAM through the turbulent waters of the post-Cold War period.

Caught in a disintegration process, which threatened to tear her apart,

* General Editor.

Asian Yearbook of International Law, Volume 3 (Ko Swan Sik et al., eds.; 0-7923-2708-X; (C) 1994 Kluwer Academic Publishers; printed in Great Britain), pp. 129-162 
Yugoslavia. like her neighbours, had apparently become convinced that only a radical change in her former political and economic policies could save the country from disaster. The Yugoslavs appeared equally convinced that for the NAM, at the global level, a similar change of policies was needed if the Movement was to survive the challenges of the new times. Hence Yugoslavia in chairing the 9th Summit of Belgrade developed and advocated what it called the "modernization of the Non-Aligned Movement"," which in fact implied the discarding of the NAM's former attitude of assertiveness vis-à-vis the two power blocs. Instead the NAM had to adopt a more tolerant and flexible position with the emphasis on cooperation and dialogue. So strongly were the Yugoslav leaders convinced of the need for this policy change that they accused those members of the NAM who disagreed with her of being dogmatic, conservative and radical. ${ }^{2}$

Many others within the NAM apparently did not share the Yugoslav views, nor were they convinced that the international political changes, however profound, would be of a permanent nature. During the formulation of the Final Documents of the Belgrade Summit, Yugoslavia's views were only partially adopted, namely where the Movement explicitly endorsed a future policy of dialogue and cooperation. At the same time, the Documents stated that while the world political climate had improved and tension had eased, peace was not stable and there was no cause for undue optimism. ${ }^{3}$

In fact, by the subsequent Ministerial Conference of the Non-Aligned Countries in Accra, Ghana, in September 1991, the world political situation had deteriorated further, including, among other things, the entire break-up of the Yugoslav federation. The report of the Accra Conference concluded that no consensus had been reached in support of the view that the Cold War had ended and that the New World Order had actually emerged. ${ }^{4}$ The meeting did, however, reaffirm its earlier commitment to a policy of compromise and consultation. $^{5}$

When the Jakarta Summit convened in September 1992, three years had elapsed since the preceding Belgrade Summit, sufficient time for the NAM finally to outline a well-defined policy for the new post-Cold War era, to be implemented this time under the leadership of Indonesia. For Indonesia, the chairing of the Jakarta Summit was the fulfilment of a long-held dream. In the

1 See for these views the writing of Dr RANKo Petkovic, the leading Yugoslav theorist on nonaligned matters, for instance in RANKo PETKovic, "Modernizing Non-Alignment," RIA No. 947, 20 September 1989, pp. 1-4.

2 Ibid: See also Darko Silovic, "Response to the Challenges of the Times," loc.cit. n. 1, pp. 4-5. 3 See Belgrade Declaration, loc.cit. n. 1, pp. 27-31, paras. 1 and 3.

4 Annex II of the Report of the 10th Ministerial Conference of the Non-Aligned Countries, Accra, 2-7 September 1991, (hereinafter referred to as Accra Report), para. 1(e), published by Media Centre of the 10th Non-Aligned Summit, Jakarta 1992.

5 Id. para. 1(g). 
1960s and 1970s the deplorable state of the Indonesian economy required that the highest priority be given to economic development. Now that the country's economy had made substantial progress, the time had come to return to the international stage and reclaim the prominent position which Indonesia had once occupied in the NAM as one of its leading founding members. ${ }^{6}$ However, Indonesia's efforts to chair the NAM, and therefore also to host and chair the NAM Summit, had been thwarted in recent years by the rival candidacy of Nicaragua. Only after Nicaragua withdrew her candidacy was Indonesia finally chosen in 1991 to host the 10th Summit.

The NAM could do little about some of the turbulent developments of the post-Cold War period (for example in Yugoslavia, Iraq, Kuwait and Somalia, all members of the NAM) and these events had a rather dampening effect on the spirit of the Movement. Moreover, critics of the Movement began to claim that the NAM had not been able to play a significant role in world affairs and that the NAM had been pushed virtually to the margins of international politics. Some even questioned whether the NAM had any role to play in the new world in which the former system of bipolarity had been transformed into one of multipolarity or, according to some, unipolarity. Some NAM members had apparently even raised the possibility of dissolving the NAM. It was against this uncertain background that the Jakarta Summit took place. ${ }^{7}$

Ultimately, around 100 members, including some 60 heads of State or government, arrived in Jakarta. The conference admitted four new members (Brunei Darussalaam, Myanmar, the Philippines and Uzbekistan), while earlier Guatemala, Mongolia and Papau-New-Guinea had also been admitted and Cambodia ${ }^{8}$ had returned to the Movement. In the meantime, one country, Argentina, had left the NAM bringing the total membership to $108 .{ }^{9}$

6 For the recent changes in Indonesian foreign policy, see M.R.J. VATIKIOTIS, "Indonesia's Foreign Policy in the 1990s," 14 Contemporary Southeast Asia (1993) pp. 353-367.

7 At the NAM Ministerial Meeting held in Larnaca, Cyprus, in early 1992, some of these pessimistic and critical comments were made even by some of the delegates, see "Non-Aligned Will Go for Changes at the UN," The Times (Malta), 5 March 1992, p. 12/1.

8 The Cambodian delegation in Jakarta was led by His Royal Highness Prince Norodom SirANOUK, President of the Supreme National Council of Cambodia.

9 Members of the NAM are: Afghanistan, Algeria, Angola, Bahamas, Bahrain, Bangladesh, Barbados, Belize, Benin, Bhutan, Bolivia, Botswana, Brunei Darussalam, Burkina Faso, Burundi, Cambodia, Cameroon, Cape Verde, Central African Republic, Chad, Chile, Colombia, Comoros, Congo, Côte d'Ivoire, Cuba, Cyprus, Djibouti, Ecuador, Egypt, Equatorial Guinea, Ethiopia, Gabon, Gambia, Ghana, Grenada, Guatemala, Guinea, Guinea Bissau, Guyana, India, Indonesia, Iran, Iraq, Jamaica, Jordon, Kenya, Kuwait, Korean Dem. People's Rep., Laos, Lebanon, Lesotho, Liberia, Libya, Madagascar, Malawi, Malaysia, Maldives, Mali, Malta, Mauritania, Mauritius, Mongolia, Morocco, Mozambique, Myanmar, Namibia, Nepal, Nicaragua, Niger, Nigeria, Oman, Pakistan, Palestine, Panama, Papua New Guinea, Peru, Philippines, Qater, Rwanda, Saint Lucia, Sao Tome and Principe, Saudi Arabia, Senegal, Seychelles, Sierra Leone, Singapore, Somalia, Sri Lanka, Sudan, Suriname, Swaziland, Syria, Tanzania, Togo, Trinidad and Tobago, Tunisia, Uganda, United Arab Emirates, Uzbekistan, Vanuatu, Venezuela, Vietnam, 
As an increasing number of other States and organizations wanted to attend NAM summits, it has become customary for the NAM to admit some of them as observers or guests at each of its summit meetings. Observers are entitled to attend summit meetings without having a vote, but, with the permission of the chair, they can speak at the meetings. Guests, on the other hand, can attend the meetings but without the right to vote or speak. In Jakarta, observer status was accorded to some eight states, including for the first time Armenia, Croatia and Thailand, and eight international and other organizations, while China had earlier already been granted observer status. Guest status had been granted to 18 States and 13 organizations ${ }^{10}$ including for the first time BosniaHerzegovina and Slovenia. Requests for guest status by Kyrgyztan and Macedonia were referred to the Co-ordinating Bureau of the Movement for further consideration.

Rather than going into the general aspects of NAM's development, the present article will devote most of its attention to some specific issues that came up as a result of recent changes in the world community. These issues which have become the subject of intense discussion among delegates and outside observers alike, are:

(1) the relevance of the NAM in the post-Cold War era;

(2) the status of the chair, Yugoslavia;

(3) the New World Order;

(4) the contribution of the NAM to international organization;

(5) the contribution of the NAM to international law;

(6) human rights; and

(7) North-South relations.

\section{THE RELEVANCE OF THE NAM IN THE POST-COLD WAR ERA}

From its very beginnings the NAM has experienced criticism, hostility and gross misunderstanding of its objectives and method of operation, often being forced to justify its raison d'être. The major criticism which had previously been made by the Western world was that it was immoral for the non-aligned countries to stay aloof from the great ideological struggle of the Cold War

cont.

Yemen, Yugoslavia, Zaire, Zambia and Zimbabwe. See "Facts and Figures about NAM Member States," The Jakarta Post, 1 September 1992, p. 3/5.

10 For the complete list of members, observers and guests attending the Conference, see Final Documents of the 10th Conference of Heads of State or Government of Non-Aligned Countries, Jakarta, 1-6 September 1992, published by PT Gramedia Pustaka Utama, Jakarta 1992 (hereinafter cited as Final Documents), Chapter I, paras, 3,4 and 5. 
between Western democracy and Eastern communism, between "good" and "evil"."11

A frequently heard and perhaps the major criticism today is that the NAM, whatever its earlier merits, has now become ineffective and irrelevant. ${ }^{12}$ In the past the NAM had vigorously pursued a policy of keeping the Third World out of the Cold War rivalry between the two superpowers and their allies. Now that the Cold War has ended, critics of the NAM maintain that the existential basis of the NAM has disappeared and with it the justification for the continued existence of the Movement.

Before going directly into the merits of these arguments, it should be said that, as often in the past, the NAM is again being subjected to a double standard. While Western international organizations, which owe their existence entirely to the outbreak of the Cold War (for example, NATO and the WestEuropean Union), continue to exist, no such accusations of irrelevance are being made against them, in spite of the official declaration by the West that the Cold War is now over and won. What is more, these organizations have been looking desperately for new or alternative objectives in order to justify and prolong their existence. In the present climate of global insecurity this poses no real problem for them.

A more direct counter-argument against the contention of irrelevance of the NAM is that its critics have allowed themselves to be deceived into wishful thinking and actually believe that the end of the Cold War automatically implies the arrival of a truly peaceful world. Carried away by euphoria, they have failed to realize that the end of the Cold War may also release certain disruptive forces which had so far been dormant. To that extent statesmen and commentators in the Third World have been more realistic and less ideological than their Western colleagues. Once signs of rapprochement between the superpowers were noticed, Third World commentators warned against expecting a speedy and substantive improvement of the international détente, since former détentes had also been expected to last and intensify, only to relapse into a new confrontation a little later. ${ }^{13}$ The continuing political unrest around the globe serves to illustrate how premature the euphoria in the West has been.

Historically, another counter-argument can be made in reply to the accusation of irrelevance. Contrary to what is often claimed, the NAM is

11 The most notorious statement was made in 1956 by the former American Secretary of State, JOHN FOSTER DULlES, who referred to "neutralism", as Non-alignment was then called, as an "immoral and shortsighted conception" (cited in PETER LYON, Neutralism (1963) p. 47).

12 A.W. SINGHAM has given much attention in his writings to frequent criticism launched against the NAM. See for instance A.W. SinghaM, "Perestroika for Non-Alignment?", RIA No. 948, 5 October 1989, pp. 8-10.

13 Cf. M.S. RAJAN, "Non-Alignment in the 'Unipolar' World”, RIA No. 982, 5 March 1991, pp. 13. Id. Jakarta Message, in Final Documents, supra n. 10, para. 3, reproduced 2 AsYIL (1992) 424. 
not the product of the Cold War although the rivalry this engendered has always greatly affected her philosophy and policies. The origins of the NAM predate the Cold War. As early as 1946, Mr. Nehru, the Indian leader projected a non-aligned foreign policy for his country stating that India intended "to keep away from the power politics of groups, aligned against one another."14 The direct precursors of the NAM: the Asian Relations Conferences of New Delhi, India, in 1947 and 1949, the Asian Powers Conference of Colombo in 1954 and, particularly, the Asian-African Conference of Bandung in 1955, were primarily convened to promote the political emancipation of dependent territories. These were mainly former colonies established after World War II, which sought protection from the dangers of returning colonialism, imperialism and neo-colonialism. The forceful return of the colonial powers (notably Britain, France, and the Netherlands) to their African and Asian dependencies immediately after the end of the Second World War, is sufficient evidence that such fears were justified. ${ }^{15}$ While it is today conceded by the NAM that colonialism is on the retreat, removing its remaining manifestations will continue to be a major preoccupation of the NAM until all peoples have exercised their inalienable right of self-determination and attained the freedom and independence of their homelands. ${ }^{16}$ Until this aim has been achieved, there is sufficient reason for the NAM to continue to function in the interest of its Members.

Politically, the NAM has always taken a firm stand against the division of the world into two rival power blocs whose massive weaponry held the world to ransom. The non-aligned States have therefore steadfastly refused to join a power bloc and insist instead on their right to pursue their own, independent foreign policy, free from pressure and domination by any country or bloc of countries. The NAM wishes to maintain that position regardless of whether there are one, two or more powerblocs. The upholding of this right remains an important task for the NAM today and in the future.

The fact, that the objectives and policies of the NAM still appeal to many States and nations is amply demonstrated by the continuing flow of new candidates applying for membership of the NAM. For instance, hardly had the break-up of the Soviet Union and Yugoslavia happened before some of their constituent States were already seeking contacts with the Movement to explore the possibility of becoming members. A similar interest in the NAM is shown by the ever-increasing number of observers and guests, including members of

14 Quoted in K.C. Chaudhary, Non-Aligned Summitry (1988) p. 2.

15 For the origins and establishment of the NAM, see A.W. SINGHAM \& S. HUNE, Non-Alignment in an Age of Alignments (1986) pp. 57-75.

16 Final Documents, supra n. 10, Chapter III (Political Issues), para. 85. 
the former Warsaw Pact, as well as some present members of NATO.$^{17}$ It is inconceivable that all these States would have bothered to attend the Jakarta Summit if they had thought the NAM irrelevant.

However, the ultimate proof of the relevance of the NAM must be provided by the NAM members themselves. Besides the expanding membership, the uninterrupted and intensifying activities of the NAM confirm that the members are fully convinced of the continued usefulness of their Movement. They are equally aware of the relative insignificance of the Third World without the combined strength of all of its members brought together in the NAM.

The NAM therefore derives its main significance from the fact that it has become the chief spokesman and main guardian of the interests of Third World countries. The NAM, however, must do some "new thinking" of its own in order to redefine its position within the new international political environment in which concepts such as Cold War, bipolarity and a three-world division are now out of date.

\section{THE STATUS OF THE CHAIR: YUGOSLAVIA}

Despite the excellent preparations of the organizers of the Jakarta Summit, the recent horrendous events in Yugoslavia could not be prevented from casting a dark shadow over the summit, adversely affecting at least the first part of the conference. Yugoslavia, a once proud country, which in the Second World War withstood the Nazi German hordes and later on the Russian "bear", had succeeded against all odds in unifying a complex multicultural society. She also became the first European country, and a founder State at that, to join Third World States in creating the NAM, only to be engulfed by civil war just as, as the NAM had long hoped for, the Cold War ended. The disintegration of Yugoslavia also threw the NAM into turmoil.

As the official chair of the Movement since the Belgrade Summit of 1989, Yugoslavia was entitled to occupy the chair until the opening session of the Jakarta Summit, when the position was to be transferred to her successor, Indonesia. However, during the preparatory meetings directly preceding the Conference, fierce objections were raised to Yugoslavia keeping the chair. In the eyes of many members, in particular the Muslim countries, the new Yugoslavia (Serbia and Montenegro) had disqualified herself by her aggressive and dehumanising treatment of the ethnic minorities of the former Yugoslavia, in particular those of Bosnia-Herzegovina. Under pressure from these

17 The list of guest countries at the Jakarta Summit showed, among others, the following names: Bulgaria, the Czech and Slovak Federal Republic, Germany, Greece, Hungary, The Netherlands, Norway, Poland, Romania and Spain. 
members, Yugoslavia had to yield the chair to Indonesia even before the official opening of the Conference. Still not satisfied, these members pressed for the expulsion of Yugoslavia from the conference. However, since the NAM does not have an expulsion procedure, they argued instead that the State of Yugoslavia had disintegrated into a number of separate States and had thus ceased to exist. Hence, Serbia-Montenegro, now called the Federal State of Yugoslavia, should, as other components of the former Yugoslavia had done, apply anew for membership of the NAM.

However, there was also support for the opposing view, that only a few constituent parts of the former Yugoslav federation had seceded but that the main body of that State, namely Serbia-Montenegro, had maintained "the state continuity and international and legal subjectivity of Yugoslavia". ${ }^{18}$ Many African countries with multi-ethnic populations themselves favoured the latter position. This debate on Yugoslavia's membership of the NAM followed in broad outline the opposing positions taken at the UN during the similar debate on Yugoslavia's membership of the UN ${ }^{19}$ There was one fundamental difference. Unlike UN decisions, NAM decisions are reached through consensus. With opposing parties so strongly divided, no consensus and therefore no decision could be reached. Therefore, the so-called Yugoslav delegation was allowed to remain at the conference pending a final decision on the legitimacy of her membership to be taken at a special ministerial meeting of the NAM in New York in September 1992. Unfortunately, this meeting could not break the deadlock either and only produced a compromise solution in which the issue was postponed for an uncertain period of time. The present chairman, Indonesia, will now attempt to resolve the matter, while Yugoslavia (Serbia-Montenegro) had agreed to suspend participation in NAM meetings and activities until its status in the international community is resolved. ${ }^{20}$

For Serbia-Montenegro in particular, which regarded itself as the continuity (in truncated form) of the former State of Yugoslavia, it must have been a bitter experience to see that the Movement which the Yugoslavia of an earlier time had helped to create and sustain, was now turning its back on them. However, the prevailing mood seemed to suggest that precisely because the former Yugoslavia had been a leading member, Serbia-Montenegro should have respected the principles of the Movement and had recourse to peaceful methods of settling the conflict. For example, they might have requested the

18 This statement was made by the Serbian foreign minister himself, VladisLav JovaNovic, in: "Settlement of the Yugoslav Crisis by Peaceful Means", RIA No. 1012-13, 1 January-1 February 1993, at p. 1.

19 See Y.Z. BLUM, “UN Membership of the 'New' Yugoslavia: Continuity or Break?", 86 AJIL (1992), pp. 830-833; "Correspondents Agora: UN Membership of the Former Yugoslavia", 87 AJIL (1993), pp. 240-251.

20 ANa Damian, "Echoes of Non-Alignment in the Balkans", RIA No. 1016-1017, 1 May-1 June 1993, p. 32. 
NAM to mediate in the matter, the more so since the other States of the former Yugoslav federation had expressed the wish to join the NAM, giving the latter considerable leverage in attempting to resolve the conflict. Serbia-Montenegro came to realize too late that resort to violence and "ethnic cleansing" were unacceptable even within a Movement which is a strong supporter of the principles of State sovereignty and of non-interference in the internal affairs of a State. ${ }^{21}$

\section{THE NEW WORLD ORDER}

The New World Order (NWO) in international relations received considerable attention at the Jakarta Summit. In the first place, the concept attracted great attention since it had been presented and developed in connection with the Gulf War, in which Iraq and Kuwait, two Arab members of the NAM, were the main protagonists. Secondly, as a movement pursuing certain international objectives, including the democratization of international relations, the reference to a New World Order involving a new system of international relations was of direct interest to the NAM. The NWO was therefore closely scrutinised to see what consequences it would have for the NAM.

The origins of the NWO lay in the disintegration of the Communist bloc in Eastern Europe and the disappearance of the rivalry between the Eastern and Western blocs during the Cold War. For the first time it became possible for the major powers, and in particular the permanent members of the UN Security Council, to pursue in unison the objectives of the UN. Apparently deeply impressed by these events and their implications for the future of the world, President George Bush of the US gave his vision of the future of international relations in a speech before the US Congress on 11 September 1990. He described the NWO in the following terms:

\footnotetext{
"A new world order ... a new era-freer from the threat of terror, stronger in the pursuit of justice, and more secure in the quest for peace, an era in which the nations of the world, East and West, North and South, can prosper and live in harmony ... Today that new world is struggling to be born, a world quite different from the one we have known, a world where the rule of law supplants the rule of the jungle, a world in which nations recognize the shared responsibility for freedom and justice, a world where the strong respect the rights of the weak."22
}

21 For a Yugoslav point of view on the difficult options she had to choose from, including those she faced at the Jakarta Summit, see RANKo PETKOvIC, "The Non-Aligned in Jakarta", RIA No. 1007-8, 1 August-1 September 1992, pp. 7-8, 29.

22 Cited in T.B. MillaR, “A New World Order?", The World Today, (1992) p. 7. 
It is quite possible, and indeed understandable, that world leaders such as President Bush, who during the Cold War period had lived for so long with the threat of annihilation by nuclear weapons, should be so carried away by the possibility of great and peaceful transformations taking place as to become convinced that the world had reached the threshold of a new and ideal world order. Others, however, regarded these developments with scepticism. When subsequent world events failed to accord with President Bush's expectations of the NWO, the prevailing situation was soon referred to in cynical terms, such as "the new world disorder". ${ }^{23}$ As could be expected in a movement of more than 100 members there were mixed reactions to President Bush's references to a NWO. Some members endorsed President Bush's vision of the NWO, and favoured strong action against Iraq in response to her attack on Kuwait, a fellow-member of the Movement. Some even contributed to the forces of the international coalition deployed in the Gulf.

However, soon after the end of the Gulf War doubts were expressed about the NWO, due mainly to the ambiguous nature and lack of clarity of the concept. There was some uneasiness that the actions of the Security Council (for example, the creation of a no-fly zone over Southern Iraq, ${ }^{24}$ might go too far in depriving Iraq of its sovereignty, and thus set a dangerous precedent. This in turn caused many in the Third World to feel that the NWO had simply become a handy policy instrument for the big powers and that the actual interpretation and implementation of the NWO had become the prerogative of the permanent members of the UN Security Council. ${ }^{25}$ The NWO ran into real trouble when it was put to the test in the Yugoslav crisis and, in the eyes of many non-aligned States, was found wanting. In this case, it seemed that the principles of the NWO were forgotten or ignored, with tragic consequences for the peoples of the former constituent States of Yugoslavia. Here, little was seen of the determination and assertiveness the Western States had demonstrated

23 Jim HoAgLAND, leading columnist of the International Herald Tribune, wrote: "All this change can sound like a script for a New World Disorder rather than for the harmonious global arrangement under American leadership that President GEORGE BusH sketched a year ago as the Gulf War ended." "Stopping Halfway along the Road to a New Order", IHT 23 April 1992. See also Stanley HoffmanN, "Delusions of World Order", New York Review of Books, 9 April 1992, pp. 37-43, and A.M. RosentHAL, "The New World Order Died in Vilnius, Age 4 Months", IHT 16 January 1991, p. $9 / 1$.

24 A couple of days before the opening of the Jakarta Summit Western countries began to enforce a no-fly zone over Southern Iraq deepening the concern of the NAM over the situation. Even a leading Western newspaper questioned the legitimacy of the action: 'No to the No-Fly Zone', IHT 29-30 August 1992, p. 10/1.

25 See the following analyses by very diverse authors: P. DE WAART, "Het westen maakt de VN oorlogszuchtig" [The West is Making the UN Warlike] in the Dutch daily De Volkskrant, 19 August 1992, p. 1/2; ANTHONY LEWIS, "So Whatever Happened to the New World Order?" IHT 29 September 1992, p. 4/3; JoHN PILGer, "Keeping the Violent Peace -the UN is Becoming an Instrument of Western Power", New Statesman and Society, 10 July 1992, p. 10. 
during the Gulf War. On the contrary, indecision and double standards seemed to characterize the policies of those countries. These contradictions did not of course go unnoticed by the non-aligned members as was evident during the general debate in Jakarta. No one expressed that reaction more dramatically and forcefully than Prime Minister Mahathir of Malaysia, who began his speech with a critique of the NWO in the light of the many crimes committed in Bosnia-Herzegovina. Why had the West adopted a hesitant attitude towards the daily killings in Bosnia having taken such strong action against "the alleged killing of the Kurds in Iraq ... even when the evidence is not clear?" Prime Minister Mahathir therefore continued:

"Is this the face of the New World Order? If it is, it is a frightening face because it is grotesquely distorted. While minor human rights infringements will attract retribution, blatant abuses on a massive scale go unpunished. What kind of New World Order is this? What will be the fate of the many small and weak countries who make up the majority in our Organization? If we are subjected to the same Serbian-type brutality, will the world watch uncaringly on their TV-screens?"26

The general feeling of discontent expressed with regard to the NWO led the NAM to decide that the formulation of the NWO could not be left to the permanent members of the UN Security Council. Hence, the NAM was determined to be actively involved in shaping the NWO. ${ }^{27}$

There was general agreement that a NWO could best be pursued at the UN, and taking into account the basic principles of the UN Charter. If the NAM had to be changed to adapt itself to the newly emerging international order, so should the UN as the centrepiece of that order itself be modified. What was particularly resented in the old order, and therefore to be abandoned in the new one, was the element of inequality built into the $U N$ as a post-war organization set up to prevent a repetition of the Second World War. Anachronisms in the UN's structure which still reflected the political configuration of the middle 1940s, including a Security Council in which each of the five principal victorious nations of World War II have been given the privileged position of permanent member and a concommitant right to wield the power of the veto, had to be eliminated.

Remarkably, even the present Secretary-General of the UN, Dr BoutrosGhali, in his much commended report on "Agenda for Peace", did not use the opportunity to suggest any structural changes to the UN system nor did he examine specific options for power distribution in a newly structured United

26 Statement by His Excellency Dato' Seri Dr. Mahathir Mohamad at the 10th Non-Aligned Summit in Jakarta, p. 6, para. 3.

27 This was already NAM's position in 1991, when the 10th Ministerial Conference in Accra, Ghana, made a statement to that effect, See Accra Report, supra n. 4, para. 1(c). 
Nations. Dr Boutros-Ghali was even reported to have said in Jakarta that it was not his job to persuade the five permanent members to revise the UN Charter; that this was almost an impossible task and that the other UN Members should themselves try in some way to persuade the permanent members to accept a change in the composition of the Council. ${ }^{28}$

In contrast, the NAM was keen to urge the restructuring and revitalization of the UN, particularly of the Security Council, although more time is needed to reach a consensus since many different opinions were expressed in Jakarta. Some members wanted an expansion of the number of permanent members of the Security Council to reflect the international reality of the 1990s. Others preferred a more democratically structured Security Council, though the elements of the idea were not precisely stated. Malaysia did suggest the use of a population criterion or at least a combination of relevant factors. ${ }^{29}$ President Soeharto of Indonesia later suggested that developing countries with a population exceeding 150 million should become permanent members of the Security Council. ${ }^{30}$ Zimbabwe proposed that any current chairman of the NAM should also be given a permanent seat on the Security Council. Other members wanted to raise the status of the General Assembly by establishing a more balanced relationship with the Security Council. No objection was heard against the possible inclusion of Japan and Germany as permanent members. However, in the case of Germany one may wonder whether-in view of the high profile of human rights protection in contemporary international relations - the frequent racial attacks on minority groups in Germany and the apparent inability or unwillingness of the German security forces to prevent such atrocities, would qualify Germany at this time for such a prominent and responsible position.

In view of the importance of this matter, participants at the Jakarta Summit thought it necessary to set up a high-level working group under the NAM's current chairperson and charge it with the elaboration of concrete proposals for the strengthening of the UN as well as the effective participation of the NAM in the shaping of the NWO. ${ }^{31}$ Although the NAM had called for a restructuring of the entire United Nations system, it was clear that the real focus of its action was the Security Council. What the NAM members really wanted, however, could hardly be expressed in the context of a huge conference where speaking time was rather limited.

A better opportunity presented itself just three months later when the General Assembly requested the Security-General of the UN to invite member

28 "Reforming UN Almost Impossible: Boutros-Ghali", The Jakarta Post, 3 September 1993, p. $1 /$ 8.

29 Statement by Dr MaHATHIR Mohamad, supra n. 26, p. 6.

30 "Falling Short in Tokyo", The Jakarta Post, 9 July 1993, p. 4/1.

31 Decision on the Establishment of a High Level Working Group for the Restructuring of the UN, (NAC 10/Doc.10/Rev.1), also published in Final Documents, supra n. 10. 
States to submit written comments on a possible review of the membership of the Security Council. ${ }^{32}$ Of the 50 replies that were returned by member States by 9 July 1993, 21 came from NAM members. What this exercise reveals is a clear affirmation of the feelings expressed on this topic at the Jakarta Summit. This time the comments went much further and into greater detail. There were clear expressions of discontent with regard to the present unrepresentative composition of the Security Council and strong demands were made for increasing the membership of the Council. Furthermore, there were strong expressions of concern about the "antidemocratic" or "anachronistic" nature of the veto which, according to some, should be abolished and about the tendency of the Security Council to expand its powers at the expense of other organs, in particular the General Assembly. There was criticism of the lack of "transparency" in the work of the Security Council and the increasing use by this organ of informal meetings as well as the inadequate reporting of the Council to the General Assembly under Article 15 of the Charter. ${ }^{33}$ It would not be surprising if these opinions were to re-emerge in the NAM Working Group on the Restructuring of the UN.

Since the organs of the UN are interrelated, the privileged position of the permanent members of the Security Council occasionally impacts on other organs of the UN even though in the latter that privileged position is not officially sanctioned by the UN Charter. It would therefore be expedient for the NAM Working Group on the restructuring of the UN also to look at the need for the restructuring of the other organs in order to bring them in line with the general trend towards a reformed UN.

The relevant organs referred to here are some of the other principal organs of the UN, in particular the Economic and Social Council (ECOSOC), the Trusteeship Council (TC) and the International Court of Justice (ICJ or "the Court"). The first two organs do not pose any real problem. The TC is slowly fading away for lack of trusteeship territories, with presently only one remaining. In the ECOSOC the five permanent members of the Security Council are still permanently represented, presumably on the basis of their economic importance and political influence. However, the undue importance attributed to the presence of permanent members has in the course of the last few decades been counterbalanced by the subsequent expansion of the total membership of ECOSOC to 54, so that in comparison with the combined influence of the 49 other members, the privileged position of permanent members has now become more plausible and acceptable.

Such is not the case, however, with the ICJ. The Statute of the ICJ sets out the composition of the Court, the qualifications of the judges as well as the

32 U.N. Doc. A/RES/47/62, 11 December 1992.

33 Report of the Secretary-General on the Equitable Representation on and Increase in the Membership of the Security Council, U.N.Doc.A/48/264, 20 July 1993. 
method of their selection. ${ }^{34}$ Today the Court is composed of 15 independent judges, elected regardless of nationality from among persons of high moral character who also have the highest judicial qualifications. The election procedure is conducted concurrently but independently by the General Assembly and the Security Council from a list of persons nominated by the "national groups" of the Permanent Court of Arbitration. In order to arrive at a broadly representative character, the electors should also bear in mind that the main forms of civilization and the principal legal systems of the world are represented in the Court (Article 9 of the Statute of the ICJ).

The electoral system of the Court has for long been subject to criticism. ${ }^{35}$ The most anomalous result of this electoral system is that while neither the Charter of the UN nor the Statute of the ICJ reserves a permanent seat on the Court for any UN Member, by having a minimum of understanding between themselves and making clever use of the electoral system, these five members (with the exception for a time of China) have been able to make sure that their national nominee would always be elected or re-elected to the Court, ${ }^{36}$ thus virtually having a permanent hold on five of the 15 seats of the Court. This represents a serious disadvantage for the other UN Members. As early as 1945, it was pointed out that in a court of only 15 members, the smaller countries would have little chance of seeing their nationals elected to it. ${ }^{37}$ Since then the electoral situation has deteriorated even further for the smaller nations. In 1946 with 15 judges forming the ICJ and the permanent members of the Security Council occupying five seats, the other 45 UN Members had to compete for the remaining ten seats. Today with more than three times as many UN members as in 1945 (namely 184), 179 Members must compete for the same ten places on the Court.

The situation might still be acceptable if the attitude of the permanent members towards the Court had shown them fully deserving of their privileged position. The facts show a different picture, though. After almost half a century of existence, the Court's records show that the permanent members of the Council are among the least supportive of the principles on which the Court is based. Although some of them have been willing to submit to the jurisdiction of the Court on the basis of a special agreement or a compromissory clause in treaties, most of them have refused to accept the compulsory jurisdiction of the Court under Article 36(2) of the Court's Statute (the so-called "optional clause") in spite of the fact that the optional clause was originally introduced to meet the objections of the Great Powers to a system of

34 Statute of the ICJ Chapter I, Organization of the Court, Article 2 et seq. 35 See Shabtai RosenNe, The Law and Practice of the International Court (1965) p. 184.

$36 \mathrm{Id}$, at pp. 185-186.

37 Ruth B. Russell and Jeanette E. Muther, A History of the United Nations Charter (1958) p. 870. 
general compulsory jurisdiction for the Court. ${ }^{38}$ They also continue to ignore the fact that as early as 1947 the UN General Assembly drew attention to the "desirability of the greatest possible number of States accepting the compulsory jurisdiction with as few reservations as possible." 39 Such an appeal was repeated as late as 1992 by the UN Secretary General in his report on "An Agenda for Peace" where he urged that the role of the ICJ should be reinforced and recommended that "all Members should accept the general jurisdiction of the International Court under Article 36 of its Statute, without any reservations, before the end of the United Nations Decade of International Law in the year 2000". ${ }^{40}$ Yet, today only one of the permanent members of the Security Council (i.e. the UK) has accepted the compulsory jurisdiction of the Court under Article 36(2) of its Statute. ${ }^{41}$ Worse still some of them have even refused to appear before the Court as defendants, or are unwilling to comply with the decisions of the Court. ${ }^{42}$

The situation will become even more complicated when, as seems certain, Germany and Japan will join the Security Council as permanent members. Will they also be assured of places on the Court? And if the efforts to restructure the UN were to lead to some Third World States also becoming permanent members of the Council, would they also be accorded the same privilege?

In 1945, when the UN was created, with the horrors of the war still fresh in the mind, there was a strong case for the introduction of permanent members into some of the UN organs given their political, economic and military importance for the reconstruction of a more peaceful post-war world. Fifty years on, however, one may question whether under completely different conditions, there is still a need for "permanent members", and if so, how they should be selected. At any rate, these questions can no longer escape close examination, since the $\mathrm{UN}$ is currently being subjected to such an examination arising from the widely felt need for the restructuring and revitalization of the UN. These efforts will focus particularly on the structure and functions of the Security Council, and therefore also on its structural linkages with other UN organs, including the General Assembly and the ICJ.

One final reason why the issue is particularly topical is that the ICJ is now increasingly being asked to pronounce on matters which have serious political, economic and military consequences for the world as a whole. The most recent example of this being a request by the World Health Organization (WHO) for

38 C.H.M. WALDOCK, "Decline of the Optional Clause", 32 BYIL (1955-56) at p. 244.

39 ROSENNE, op. cit. n. 35, Vol. 2, Appendix 9, p. 879.

40 U.N.Doc. A/47/227, 17 June 1992, para. 39(a).

41 International Court of Justice, Yearbook 1991-1992, Chapter IV, Section II: Declarations Recognizing as Compulsory the Jurisdiction of the Court, pp. 73-111, at 73 (footnote 1) and 109. 42 For more facts and statistical data, see ReNATA SzAFARZ, "Changing State Attitudes towards the Jurisdiction of the International Court of Justice", in: A. BLOED and P. vAN DIJ,, Forty Years International Court of Justice: Jurisdiction, Equity and Equality (1988) pp. 1-26, at 20-21. 
an advisory opinion of the Court on the legality of the use of nuclear weapons ${ }^{43}$ It is therefore of the utmost importance that the composition of the Court effectively and equitably reflects the present UN membership rather than reflecting the situation of 50 years ago.

\section{THE CONTRIBUTION OF THE NAM TO INTERNATIONAL ORGANIZATION}

When, after World War II, newly independent States embarked on a process of international cooperation, it might have been expected that they would follow existing models of international organization which had already proven their usefulness. However, these States seem to have preferred to strike out along new paths in the field of international organization and have experimented with different structures which they regard as more suitable for their purposes: the founding fathers among the non-aligned endorsed a form of cooperation that was not an international organization, but a movement. ${ }^{44}$ The NAM was not set up by treaty or convention. It has no constitution, no specific rules of procedure, no permanent secretariat, no annual budget, and no international legal personality. It functions in a fairly loose and flexible manner, guided by accepted principles and practices, and taking decisions only on the basis of consensus. In fact, the First Non-Aligned Summit at Belgrade in 1961 was convened as an ad hoc international conference without the intention of making it a periodical event. Only later did the members decide to have a summit meeting every three years.

The reasons for choosing this model have their roots in the history and early experiences of the States concerned. As former colonies which had fought long and hard for their freedom, they had the tendency to be jealous of their newly won independence and sovereignty, and were inclined to look with some suspicion on any structure that would require the surrender of any of their powers as States. They also feared that an international organization created for the purpose of achieving the common goals of the members, could in course of time become an end in itself and start to pursue its own interests rather than those of its members. Some of the founders of the NAM felt that traditional international organizations could be less than democratic in their internal operation, often enabling the more powerful States to monopolize important functions.

43 Resolution of the Assembly of the World Health Organization on Health and Environment Effects of Nuclear Weapons, 8 May 1993, requesting the ICJ to give an advisory opinion on the following question: "In view of the health and environmental effects, would the use of nuclear weapons by a State in war or other armed conflict be a breach of its obligations under international law including the WHO Constitution?" This request has now been officially confirmed by the ICJ in its Communique of 13 September 1993. 
However, it was eventually conceded that to make international cooperation a success, some basic structures were necessary, if only to enhance internal communication and the implementation of agreed policies. As the membership came to feel the need for periodical meetings and permanent and regular organs, the Movement gradually adopted more of the characteristics of the traditional international organization than had originally been intended.

The two principal organs of the NAM are the Conference of Heads of State or Government (the Summit), the primary policy-making body which convenes every three years, and the Foreign Ministers Meeting, which is convened at least twice in three years. Both have become regular organs, as has the Chair which is customarily assigned to the host State for the duration of three years until the next summit. For the crucial task of co-ordinating the NAM's activities there is a Co-ordinating Bureau operating at two levels, namely that of the Ministers of Foreign Affairs, meeting at least once a year, while the Permanent Representatives of the non-aligned countries at the UN meet in New York as often as the business of the Movement requires.

On political matters, much preparatory work is done by working groups dealing with special issues. As to economic issues, the increased attention being paid to development problems is reflected by functional bodies, each responsible for a particular field of activity covered by the Action Programme for Economic Cooperation among Non-Aligned Countries. ${ }^{45}$

While at a superficial level the present NAM might appear structurally to resemble other international organizations, it is markedly different from most of those bodies in that it does not have, nor does it desire, a permanent secretariat. Instead the chair is expected to provide, during a three-year term of office, the administrative and technical support usually furnished by a permanent secretariat. Members, including a former chairperson (President Robert Mugabe of Zimbabwe) have frequently proposed that a permanent secretariat be created, but time and time again the proposal has been rejected, apparently for fear that a permanent secretariat would signal the creation of an unwieldy and expensive bureaucracy often associated with traditional international organizations.

An important feature of the NAM is that all decisions are arrived at by consensus. For a Movement that includes countries with widely different political and social systems, and peoples of various ethnic and cultural origins, the adoption of consensus rule might seem to be to court disaster. However, NAM members could in turn argue that, to ignore these differences and to

44 The Accra Report states explicitly that "the Movement is not an organization", Accra Report, supra n. 4, Annex III, para. 3.

45 The best source for non-aligned material is as yet ODETTE JANKowitsch \& KARL P. SAUvANT, The Third World without Superpowers-The Collected Documents of the Non-Aligned Countries, Oceana Publ., New York (1978). 
impose majority decisions on such a diverse gathering of States, would inevitably lead to the break-up of the Movement. This fundamental and perennial dilemma that the NAM faces has to be kept in mind if one is to understand the often slow and arduous method of operation of the Movement. ${ }^{46}$ It is the price that the Movement has to pay for its survival and a price that so far it has been quite willing to pay. Media and professional observers, even from the Third World, who are not restrained by the responsibility of holding the Movement together, can sometimes be far more critical than non-aligned leaders themselves of the way the Movement functions. They feel that the price is too high and that progress is too slow. One Indonesian newspaper had this to say about the important meeting of the Standing Ministerial Committee for Economic Cooperation in Bali in May 1993:

\begin{abstract}
"The outcome fell short of what we originally expected from the meeting at such a level. We actually expected at least clearly-designed blueprints of workable cooperation programs between the NAM members themselves ... Instead the committee has set the Movement into a seemingly endless series of future meetings by proposing the establishment of two ad hoc advisory groups of experts and the convening of a summit meeting on economic and social development and international cooperation, as well as another conference on development issues. The sheer process of forming and arranging the composition of the advisory groups and the uphill and very costly exercise of preparing for a summit meeting will have heavily taxed the scarce resources of NAM before it can even begin to embark on concrete cooperation projects ...,"47
\end{abstract}

The NAM is itself clearly aware of the need to assess its performance periodically and introduce changes if they are called for. In 1988 a committee was set up, strikingly designated the Committee on the Methodology of the Movement, which was given the task of examining the working methods and procedures of the Movement in order to make it more effective. ${ }^{48}$ One of its suggestions that was discussed in Jakarta was the creation of a Back-up System to the Coordinating Bureau which, in the absence of a secretariat, could provide the necessary services and continuity. In its report to the Summit Conference in Jakarta, the Committee recommended that the back-up system would comprise senior representatives of Permanent Missions to the UN in New York. ${ }^{49}$

46 For the operation of the consensus rule in the NAM, including the decisive role of the Chairman, and the use of reservations, see SingHAM \& HUNE, op. cit. n. 15, at pp. 43-47, 114-116 and 311-313.

47 "The View from Bali", The Jakarta Post, 17 May 1993, p. 4/1.

48 Accra Report, supra n. 4, Annex II, para. 1-1.

49 "NAM Ministerial Meeting Agree(s) to Adopt Recommendations for Summit", Summit News, published by the Media Centre of the 10th Non-Aligned Summit, Jakarta, 1 September 1992, p. A-6. 


\section{THE CONTRIBUTION OF THE NAM TO INTERNATIONAL LAW}

The NAM is essentially an informal movement pursuing certain commonly agreed objectives and ideals without imposing legal obligations on its members, and without relying on the kind of structural support provided by a regular international organization. Since it is not an international legal person, the NAM has no capacity to enter into legal relations under international law. It does not, for example, conclude treaties.

This does not mean that the NAM is unable to influence the development of international law. In fact, the views of its members are heavily influenced by the policies and positions adopted by the Movement. Non-aligned summit meetings are convened, in part, to undertake a collective assessment of the international situation and enable the members jointly to formulate the NAM's position on certain important general and specific issues. The Final Declarations of each summit meeting represent the official position of the NAM arrived at by consensus. Hence, it is natural to assume that NAM members, who have participated fully in the formulation of these policies would generally support them and feel morally bound to bring their own policies into line with those of the Movement. In this way State practice among some 100 States is being influenced on such issues of general importance as the New World Order, human rights, the environment and the restructuring of the UN, as well as on more specific issues, such as the situation in the Gulf, BosniaHerzegovina, Somalia, Western Sahara and South Africa. Efforts are also continuously being made at the UN by the Coordinating Bureau of the NAM, as well as by the non-aligned caucus or non-aligned groups in the various organs of the UN, to achieve some degree of coordination of the activities and policies of non-aligned countries. With so many of its members adopting, or at least being influenced by NAM positions, State practice among them will inevitably tend to show a considerable degree of uniformity. In this indirect way the NAM has a clear influence on the development of international law.

One international law concept which is of relevance to non-alignment and keeps interacting with it, is neutrality. Although neutrality shares certain common characteristics with non-alignment, the concepts are in other respects different. In general, neutrality is a position of non-participation or noninvolvement in a war between belligerents. Non-alignment, often earlier called "neutralism", is non-involvement in, or dissociation from, a particular type of war, the "Cold War", a rivalry and conflict between two powerful States, in which contending parties pursue their objective by a variety of means short of war. ${ }^{50}$ Historically, both concepts have gained in importance as methods by

50 For an early comparative discussion of neutrality, neutralism and neutralization, see PETER LyoN, op, cit n. 9, Chapter I and IV. At one time Sweden held a rather particular view on her neutrality. Her Minister of Foreign Affairs, STEN ANDERsson, stated in 1986 that "we define our 
which States defend their independence by staying outside international conflicts and wars. Neutrality has, however, in course of time achieved recognition as a legal status, conferring rights and duties on belligerents and neutral States alike.

Such is not the case with non-alignment, in spite of forceful support for its legal status from several jurists. As a Movement dependent entirely on the voluntary support of its Members, non-alignment cannot expect to create legal obligations for its adherents, let alone for other members of the international society of States. The Yugoslav jurist Petkovic is on sounder ground when he stresses that because of its constant support for, and emphasis on, the UN and the principles of the UN Charter "as the 'constitutional' norms of the present legal order", the NAM has been expanding its base in international law. ${ }^{51}$

After World War II neutrality has lost some of its importance because the post-war legal system forbids war. As non-alignment arose as a response to the Cold War, the end of the Cold War could have a similar impact on nonalignment. Neutrality, on the other hand, may now be undergoing a renaissance, for in a new world wherein regional disputes and ethnic confrontations seem to have replaced the Cold War, third States may increasingly want to remain aloof and avail themselves of the neutral option in case such conflicts were to erupt in war. A revival of the practice of neutrality may therefore be expected in contemporary and future international relations.

Paradoxically, at this very time of the resurgence of neutrality, some longstanding champions of the concept (e.g. Sweden, Switzerland, Finland and Austria) are considering modifying their traditional policy of permanent neutrality. This change of policy may be the price that they have to pay for joining the European community (EC) and share in the riches expected from economic cooperation within it. Yet it seems that, in their negotiations with the EC, some mode of accommodation may still be found that will enable them to keep some measure of their traditional status of neutrality. ${ }^{52}$ Some experts have even suggested that in the future Europe there may be room for a socalled "cooperative security system" in which a redefined type of neutrality would have its own role to play. It might even be conceivable that a "corridor of neutral States" would be necessary to secure peace between the new power concentrations of Western Europe and the Confederation of Independent

cont.

main foreign policy line as 'non-participation' in alliances in peacetime with a view to neutrality in war," "Neutrality and Non-Alignment," RIA No. 872, 5-20 August 1986, p. 7.

51 Ranko PetKovic, "Non-Alignment and International Law", RIA No. 575, (1974) pp. 23-26 at p. 26.

52 SuRYA P. SuBEDI, "Neutrality in a Changing World: European Neutral States and the European Community”, 42 ICLQ (1993) pp. 238-268, at p. 258-259. 
States in Eastern Europe. ${ }^{53}$ However, it could well be that the EC, which is already facing serious problems in its integration efforts, may not look very favourably on conditions suggested by new applicant States if such conditions have the potential further to complicate and hold up the creation of a European Union which aspires to adopt a common foreign and security policy, and eventually even a common defence policy. ${ }^{54}$ This again underlines the fact that the concept of neutrality is showing two trends: a trend that strengthens its further development, and a counter-trend which could retard it.

As a result of the integration processes taking place in Europe, a number of European members of the NAM are now aspiring to join the EC. Malta and Cyprus, two of the three oldest European members of the NAM, have already entered into negotiations with the EC. Some of the new republics which emerged from the Yugoslav tragedy and are now either member or observer (i.e. a potential member) of the NAM, may in due time also consider entering into some form of cooperation relations with the EC. ${ }^{55}$ The question of the compatibility of a NAM membership with an EC or EU (European Union) membership will then have to be faced by all parties, because the foreign and defence policies of the EC or EU might sometimes be at variance with NAM's policies.

In areas such as this the NAM may have to adopt innovative policies to respond to the profound changes that are reshaping the world that existed during the Cold War. Towards the end of that period the NAM became more lenient towards applicant States with some involvement in military alliances. In the present world, where the dangers of military confrontation between the two major military alliances no longer exist, and where the UN, in particular the Security Council, is able to perform its major function of maintaining international peace and security, there would appear to be no reason to deny NAM members the right to join regional international organizations, even those with their own defence policies. Moreover, one of the strong points of the NAM has always been the extensive network of international diplomatic contacts which it is able to use through its large and varied membership. Thus, non-aligned members such as Cyprus and Malta, who have been long-standing and faithful members of the NAM, may well be able to serve as useful channels of communication if they were to be admitted to the European Union. At any rate, these countries could always remain within the non-aligned circle as observers. If for some reason no mutually agreeable solution could be found they would be entirely free to leave the Movement, since the NAM does not

$53 \mathrm{~J}$. BiNTER, "Neutrality in a Changing World: End or Renaissance of a Concept?", 23 Bulletin of Peace Proposals (1992) pp. 213-218.

54 For the process of establishing a European Union, see e.g. Towards a European Union (publication of the Commission of the European Communities, 1992).

55 Europe and the Challenge of Enlargement (Bulletin of the European Communities, Suppl. 3/92, Brussels, 1992) pp. 17-20. 
have any rule preventing a member from leaving if it so desires.

Although, as a loosely organized political movement, the NAM may not be the most suitable forum for carrying out a concrete project for the progressive development of international law or its codification, its initiatives in organizations better equipped for such tasks can stimulate the development of international law. It was one such non-aligned initiative that led to the launching of the UN Decade of International Law. In June 1989 an extraordinary Ministerial Meeting of the NAM was convened in The Hague to discuss the issue of peace and the rule of law in international affairs. The meeting adopted the Hague Declaration on Peace and International Law (Hague Declaration). It expressed many of the non-aligned views on the need for peace and harmony between nations and
"called upon the United Nations General Assembly to declare a Decade of International Law to begin in 1990 and conclude in 1999, marking the centennial of the first Peace Conference held in The Hague, and to provide for the establishment of a commission led by a distinguished international jurist to organize and conduct the activities of the Decade of International Law and to prepare a Third Peace Conference at its conclusion." 56

In spite of the lukewarm, and at times rather hostile, response from Western States, the General Assembly finally adopted Resolution 44/23 on 17 November 1989, declaring that the period 1990-1999, the UN Decade of International Law, should be devoted to the strengthening of the international legal order. ${ }^{57}$

As for the second proposal, the Sixth (Legal) Committee of the General Assembly has set up a Working Group on the UN Decade of International Law which has already produced reports presenting a programme of activities for the first term $(1990-1992)^{58}$ and the second term (1993-1994) ${ }^{59}$ of the Decade. However, in the face of certain objections from some major UN members the proposal for a Third Peace Conference has not yet been pursued.

The Hague Declaration contained certain broad suggestions as to the nature of the work that could be undertaken in the Decade of International Law. General Assembly Resolution 44/23, adopted in implementation of the initiative of the NAM, redefined and restricted the scope of the Hague Declaration and affirmed that the main purposes of the Decade should be, inter alia:

56 The Hague Declaration of the Ministers of Foreign Affairs of the Movement of the Non-Aligned Countries Meeting to Discuss the Issue of Peace and the Rule of Law in International Affairs, (NAM/ Conf. 8/P.R.L./MM/2/Rev.1.) at p. 8.

57 See Jeremy Thomas, “The United Nations Decade of International Law", 3 Afr.JICL (1991) pp. 386-398.

58 U.N.Doc. A/C.6/45/L.16.

59 U.N.Doc. A/C.6/47/L.12. 
(1) to promote the acceptance of and respect for the principles of international law;

(2) to promote the means and methods for the peaceful settlement of disputes between States, including resort to and full respect for the International Court of Justice;

(3) to encourage the progressive development of international law and its codification; and

(4) to encourage the teaching, study, dissemination and wider appreciation of international law.

The history of the adoption of the UN Decade of International Law is another example of the now familiar phenomenon: when Western and Third World countries have different political interests regarding important global issues, focus on the legal aspects of such a particular issue readily produces controversy. ${ }^{60}$ In this connection it is worth noting that the NAM acts as initiator or promoter of the Third World views on international law. For instance, the NAM has consistently emphasized, and thus contributed to the consolidation of international law on such concepts as non-interference, sovereignty over natural resources and economic self-determination.

In some ways the Third World States may now be said to replace Western countries as the most ardent supporters of international law and have seemingly embarked on a "crusade for international law". ${ }^{61}$ Fully aware of their strength in numbers they miss no chance to stimulate its progressive development, as was demonstrated in the early calls for a New International Economic Order, ${ }^{62}$ and more recently in initiatives to formulate the nonaligned position on human rights and to bring about a UN Decade of International Law. Moreover, intent on the promotion of the role of international law in the settlement of international disputes, the NAM has frequently recommended that States, members as well as non-members of the NAM, resort to the ICJ and comply with its judgments. ${ }^{63}$

In view of its disagreements with Western countries, it might be worthwhile for the NAM to give more consistent attention to the legal bases of its claim, as these may at times become the object of strong opposition from Western countries. It is equally desirable for the NAM not only to limit itself to the taking of initiatives in the field of international law but to consider setting up its own legal committee to be composed, for instance, of international law experts from ministries of foreign affairs, legal departments or academic institutions of member States. The primary task of such a committee would not only be to underpin the legal initiatives of the NAM but also to anticipate and

60 JeRemy THOMAS, loc. cit. n. 57 at p. 388 and 395-6.

61 M. Brus, “A Non-Aligned Crusade for International Law?", 2 LJIL (1989) pp. 240-247.

62 See Singham \& HUNe, op. cit. n. 15, pp. 22-25.

63 See Hague Declaration on Peace and the Rule of Law, supra n. 56, p. 4. 
prepare for the crucial legal controversies of the future. The human rights debate is a case in point.

\section{HUMAN RIGHTS}

It is a measure of the prominent position which the human rights issue is now taking in international affairs that it has also become a major topic in discussions at Jakarta. For the first time in the history of the NAM Summits, the Movement dealt directly with the human rights issue and formulated its own official position to which it devoted a special section, both in its Final Documents, as well as in the Jakarta Message. ${ }^{64}$

It was the discussion of the NWO which first raised the issue of human rights, particularly in reference to events taking place in Yugoslavia and Bosnia-Herzegovina. In addition, the current situations in South Africa, Somalia and Cambodia obviously drew attention to the deplorable state of human rights in these countries.

The case of East Timor, however, was not formally raised, probably because during the summit new, informal initiatives were taken by, among others, the Secretary-General of the UN, Dr Boutros-Ghali. who attended the Jakarta conference as an official guest. When the Indonesian Government intimated that it was willing to discuss the matter with the Portuguese Government without making any pre-conditions, Dr Boutros-Ghali invited both parties to meet in New York during the following UN General Assembly to take place a few weeks later. ${ }^{65}$ The sensitive and complex nature of the dispute is indicated by the fact that after several rounds of negotiations not much progress has yet been reported. ${ }^{66}$ However, as long as relations have not been completely severed, there remains the possibility of a breakthrough. In July 1993, it was reported that some East-Timorese leaders living in exile in Portugal sought to open lines of communication with pro-integration leaders in East Timor. President Soeharto of Indonesia has apparently given his approval for such a dialogue. ${ }^{67}$

64 Final Documents, supra n. 10, Chapter 2 (Global Issues), Section G (Human Rights), paras, 7380; Jakarta Message, supra n. 13, para. 18.

65 "Boutros Ghali: RI, Portuguese Foreign Ministers to Meet", Summit News, published by the Media Centre of the 10th Non-Aligned Summit, Jakarta, Indonesia, 2 September 1992, p. A-9.

66 “Talking about East Timor", The Jakarta Post, 21 April 1993, p. 4/1; "Indonesia, Portugal Open 'Confidence Building' Talks, The Jakarta Post, 22 April 1993, p. 1/4. See on the third tripartite talks between Indonesia and Portugal, "Alatas Sees Progress in East Timor Talks with Lisbon", The Indonesian Times, 18 September 1993, p. 8/1.

67 "President Agrees to Hold Dialogue with East-Timorese Figures", The Indonesian Times, 21 July 1993, p. 1/7; "East Timorese in Exile Seek Dialog: Lopez da Cruz", The Jakarta Post, 21 July 1993, p. $1 / 3$. 
One of the main reasons for the important role that the human rights issue played in Jakarta was the effort made in recent years by the Western world to mobilise world public opinion for the protection of human rights. The Western emphasis is so great that human rights have now become a major foreign policy objective of Western Governments. In pursuing these policies they have taken on themselves the task of monitoring the performance of other countries, and censuring them when, in their opinion, these countries fail to perform satisfactorily. It would be only one step further to take certain measures against these countries for actual or alleged violation of human rights. It is here that the strongest protests are made by the NAM for what they consider a violation of the sovereignty of the State and interference in domestic affairs.

Strong reactions to the Western position on human rights were heard during the general debate. For instance, $\mathrm{Mr}$ Nyerere rejected the "exclusively individualistic definition of human rights." 1992 Jakarta Summit the Western position is rejected and NAM's own view is defended. Since the official position of the Summit as laid down in the Final Documents does not amount to more than a brief series of general statements presenting the non-aligned position on human rights issues, and in views of the prominence given to human rights in the world at large, this chapter aims to deal more extensively with some aspects of the human rights issue as they were raised as a result of the discussions in Jakarta.

Contrary to what had been anticipated by those outside the Movement, the conference did not reject the binding nature of human rights. In fact, the heads of State or government explicitly affirmed the universal basis of basic human rights and fundamental freedoms that serve as a common standard of respect for the dignity and integrity of man. ${ }^{69}$ However, they added some of their particular and more relativist views on human rights. For example, they upheld the competence and responsibility of national governments in the implementation of human rights and they stressed that the promotion of human rights should take greater account of varying historical, political, economic, social, religious and cultural realities, and of the balance between the fundamental rights and freedoms of the individual and his obligations to society and the State, as embodied in the Universal Declaration of Human Rights. ${ }^{70}$ They also particularly stressed the indivisible nature of human rights which precludes the neglect of economic, social and cultural rights in favour of civil and political rights. In addition, they reaffirmed their conviction that the right to

68 Statement by His Excellency Mr Julius Nyerere, former President of the United Republic of Tanzania and Director of the South Centre, Jakarta, September 1992, p. 10.

69 Final Documents, supra n. 10, Chapter 2 (Global Issues), para. 73.

70 Id, para. 74. 
development is an integral part of fundamental human rights, ${ }^{71}$ as is the right to self-determination. ${ }^{72}$

Strong objections were raised against certain tendencies which have developed elsewhere with regard to the promotion of human rights. NAM members assert that no country should use its power to dictate its own concept of democracy and human rights or to impose conditionalities on others ${ }^{73}$ as is often done with regard to socio-economic assistance. ${ }^{74}$ No country or group of countries should arrogate to themselves the role of judge and jury over other countries on this sensitive and critical issue which is of concern to the entire international community, nor should human rights be used as instruments of political pressure, since all nations have the right freely to establish their own political and economic systems and institutions on the basis of respect for the principles of national sovereignty, self-determination and non-interference in the internal affairs of others. ${ }^{75}$

For a possible accommodation of these various conflicting views the NAM points to the fact that the UN Charter has placed the question of universal observance and promotion of human rights squarely within the context of international cooperation ${ }^{76}$ and its members explicitly commit themselves to cooperating in the protection of human rights. ${ }^{77}$ The above statements also raise the questions of the political and moral aspects of the human rights issue.

In their desire to promote the worldwide protection of human rights, Western countries have not hesitated to use a mixture of overt and covert pressures in the political, economic, financial, artistic and even sporting (e.g. the threat of boycott of future Olympic Games in China) fields, for which purpose, when necessary, their entire diplomatic machinery is activated. It is questionable, though, whether the resolution of such a sensitive and morally important issue as human rights is best promoted by use of such methods. Moreover, Western policy makers who must certainly be aware that their own human rights record is far from perfect, should be slow to set themselves up as the immaculate champions of human rights, since the tables could be turned on them occasionally. ${ }^{78}$

There were early indications that Western countries intended to use the opportunity of the Second World War Conference on Human Rights in Vienna in June 1993 to push through their own views on the nature and importance of human rights, and by implication criticize those who took a different stand. It

71 Id, para. 75 .

72 Id, para. 76.

73 Jakarta Message, supra n. 13, para. 18.

74 Final Documents, supra n. 10, para. 75.

75 Id, para. 73.

76 Ibid.

77 Jakarta Message, supra n. 13, para. 18.

78 “Asians, Turning Tables, Denounce EC in Bosnia", IHT 28 July 1993, p. 2/2. 
was, therefore, to be expected that the developing countries would also prepare themselves for such a confrontation, using their own legal and diplomatic instruments and making full use of their group bargaining and voting strength.

In the Final Documents of the Jakarta Summit the NAM therefore outlined its strategy and called on its members to:

"coordinate their positions and actively participate in the preparatory work of the Second World Conference on Human Rights in June 1993, in order to ensure that the Conference addresses all aspects of human rights on the basis of universality, indivisibility, impartiality and non-selectivity."79

If anything, human rights are a moral issue par excellence and are indeed being dealt with and debated in highly moral terms. While the issue of human rights has a long history, it only gained real prominence as a result of the horrors experienced in the two World Wars, in particular the barbarism perpetrated by some of the warring parties on civilian populations in general, and on certain social and ethnic groups in particular. These shocking experiences gave the Western countries ample cause to try to mobilize the entire post-war international community in an effort to prevent any repetition of such atrocities. After the Second World War the protection of human rights was pursued by the West as a primary objective and with a single-mindedness which was, at first, quite commendable.

However, because of their obsession with the Cold War, Western countries began to use the human rights issue as an instrument of pressure and propaganda with which to attack the Communist governments of Eastern Europe for their gross violations of human rights, embarrassing them in the eyes of both their own people and the outside world. The success of this effort has apparently led the West to believe that the same missionary zeal could be used against the countries of the Third World. One may question, however, whether the moral justification for the West to impose human rights standards on the Communist world holds equally for the Third World.

In the first place, the Third World was not party to, nor guilty of, waging the World Wars which resulted in the deaths, disablement and displacement of millions. Some writers in the Third World still prefer to speak of "the Great European Wars" or "the European Civil Wars" 80 for which they feel no guilt or responsibility. While massive violations of human rights have also occurred and still occur in the Third World, the Second World War conclusively demonstrated that some of the most heinous atrocities in World War II were committed in some of the most "civilized" and "advanced" countries in the world.

79 Jakarta Message, supra n. 13, para. 18.

80 K.M. PANIKKAR, Asia and Western Dominance (1953) pp. 259 et seq. 
Secondly, the idea seems to exist that Western policies successful in the Communist world would also be successful in the Third World. The fact is overlooked, however, that the historical and political context of Western involvement in Eastern Europe is quite different from that in the Third World. In relation to the Third World, some countries in the West bear heavy responsibility, at least in moral terms, for their imperialist and colonial adventures and the suffering inflicted upon indigenous peoples which makes it more difficult for them to claim to be able to lead by way of example.

Even the present record of some Western countries can hardly be described as perfect. Although these countries have made important progress in the protection of human rights in their own societies, many problems, such as discrimination against and vicious attacks upon groups in their societies-for instance, Jews, homosexuals, refugees and migrant labour-remain unresolved. Their record is particularly poor with regard to racial discrimination. Indeed, it is now generally admitted that racism is on the rise across Europe. ${ }^{81}$

The point to be made here is not that human rights are not important or do not deserve so much attention: no measure of attention could today be too much to defend the cause of human rights, and the Third World with its long history of colonial and post-colonial human exploitation and suffering would and should be the first to recognize this. However, it is worth emphasizing that the cause of human rights will not be advanced through aggressive and selfrighteous action.

Western countries often fail to see that their attitude towards human rights is open to criticism as being Eurocentric. The record concerning human rights in the Third World, as indeed in the West, has been determined by historical, political, religious, economic and other realities. It is doubtful whether, without the historical experience of the massive human suffering in Europe in World War II, and the resulting sense of guilt and responsibility for the slaughter of the Jewish people, the States of Western Europe would have developed so great a concern for human rights and fundamental freedoms.

The Second World Conference on Human Rights in Vienna in June 1993, which started in an atmosphere of disagreement and recrimination, did not, therefore, produce the positive results for which the world had been waiting. With the negotiating parties so strongly divided on crucial issues, one could hardly expect the conference to run smoothly and productively. It was remarkable that a final document could be adopted by consensus in time, even though it cannot be said to be a model of clarity and coherence. If the end result was therefore not satisfactory, it was the best that could be achieved at the time. Only time will tell whether this result is sufficient to form the basis for a positive long-term development of human rights.

81 "Stamping out the Scourge of Racism", The Guardian, London, 20 February 1993, p. 14/1. 
For the NAM, as the initiator of policies for the Third World, it might be worthwhile to look into the possibility of a special review session for its own members in order to assess the impact of the Vienna Conference on its own position. This would also be an appropriate opportunity to compare the differences in human rights approaches existing between its African, Asian and Latin American members. An open exchange of views and experiences between these continental or regional groups might be useful in order better to coordinate, rationalize and consolidate a general non-aligned position with regard to human rights. It is a fact that the human rights issue has increasingly engaged the imagination and emotion of the general public, both internationally and domestically. The adoption by the NAM of a well-balanced and progressive non-aligned position on human rights will therefore not only enhance NAM's prestige in international relations, but it will at the same time go a long way towards meeting the legitimate demands of their own citizens for better observance of human rights.

One general lesson of the Vienna Conference is therefore that to clear the atmosphere in the human rights debate, one must accept that only through cooperation and dialogue, as foreseen in the UN Charter, and not one of recrimination and self-righteousness, could progress be achieved toward universal respect for human rights.

\section{NORTH-SOUTH RELATIONS}

Over some two decades the centre of attention of the NAM has been shifting from the great political issues of the post-war era (e.g. Cold War confrontation, the arms race, colonialism, racism and foreign intervention) to the economic and development issues of today (for example, the North-South dialogue, the debt issue, international trade and commodity prices, and South-South cooperation). This is quite understandable in the light of the fact that after having achieved their political independence, the new States soon became aware of the fact that in economic terms their independence was impaired by the working of world economic forces beyond their control. This shift in emphasis has become more prominent in recent times not only because of the impact of the global recession but also because of the growing concern among non-aligned States that in the interests of European and perhaps world stability, the Western world will have to divert much of its resources to the political and economic development of Eastern Europe. This may eventually result in a decreasing flow of capital and other resources to the developing world.

Under the leadership of Indonesia, whose national policies give high priority to the search for development, the Jakarta Summit has paid special attention to development issues. It should be noted that in contrast to the NAM's approach 
towards international political issues, it has now come to admit openly that "without establishing ties and dialogue with the developed world there can be no solution to economic problems facing our countries." ${ }^{, 2}$ On the other hand, it has to be borne in mind that interdependence also means that the sustainable development of the North will not be possible without a reasonable measure of development and stability in the South. The Jakarta Summit called, therefore, for the reactivation of a constructive dialogue between the North and the South, this time to be based on genuine interdependence, mutuality of interests and benefits, and shared responsibilities. ${ }^{83}$ The high priority given to NorthSouth relations was also demonstrated by its decision to reactivate the Standing Ministerial Committee for Economic Cooperation, which had been dormant for some time, and charge it with the task of finding new ways of restarting the dialogue.

An inseparable part of NAM's development strategy, is the so-called SouthSouth cooperation, cooperation among developing countries themselves. The Conference appealed to its members to intensify such cooperation in order to promote their own development and reduce undue dependence on the North. To that end, members should endeavour to initiate concrete and practical forms of cooperation in such areas as food production and population, trade and investments, and should devise realistic modalities for their implementation. ${ }^{84}$ Furthermore, trade and other economic activities should be expanded and if possible pursued through, for example, cooperation or technical assistance agreements between NAM member countries. During the Jakarta Summit several such agreements were concluded. ${ }^{85}$ It was also felt that success in South-South cooperation was a pre-condition for the strengthening of the bargaining position of the South in future negotiations with the North. Following up quickly on the decisions by the Jakarta Summit, the Indonesian Chairman drew up and proposed an Economic Agenda for Priority Action 1992-1995 to be implemented during the three-year chairmanship of Indonesia. The Agenda comprises among other things such issues as external debt, food security and population, commodities, the Uruguay Round, South-South trade promotion, as well as the strengthening of international cooperation and developing support mechanism. ${ }^{86}$ Indonesia also convened a meeting of the

82 Belgrade Declaration, supra n. 3, Section II, para. 7.

83 Jakarta Message, supra n. 13, para. 16.

84 Jakarta Message, supra n. 13, para. 17.

85 See e.g. "RI [i.e. Republic of Indonesia] to Offer Technical Environment Assistance to NAM Countries", Summit News, published by the Media Centre of the 10th Non-Aligned summit, Jakarta, Indonesia, 27 August 1992, p. AZ-11; "RI Takes Opportunity of NAM to Sign Cooperation Agreements", Summit News, 4 September 1992, p. A-1.

86 "NAM Chairman's Plans: Economic Agenda for Priority Action 1992-1995", South Letter, published by the South Centre, Geneva, No. 15, Autumn 1992, pp. 14-16. 
Standing Ministerial Committee for Economic Cooperation in Bali as early as May $1993 .{ }^{87}$

For the realization of the North-South dialogue, it was also thought necessary to strengthen cooperation with the group of seventy-seven (G-77). The current chairman of the G-77, Colombia, was also present at the abovementioned Bali meeting. Earlier there had been suggestions that the NAM and G-77 should be merged, but they were always decisively rejected. Instead a Joint Coordinating Committee (JCC) was established to improve exchange of views and coordination between the NAM and the G-77. The JCC is comprised of the present and immediate past chairmen of the NAM and the G-77 and meets every three months. ${ }^{88}$

Equally important for the success of the North-South dialogue, in the opinion of the NAM, was the improvement of its relations with the group of seven major industrialized countries (the G-7), whose support would be crucial for the success of a new North-South dialogue. It was also hoped that, conversely, the North would realize that in an increasingly interdependent world the link between development in the South and world peace and global stability will become progressively stronger, making a speedy resumption of the North-South dialogue a real necessity for both parties. Immediately after the Jakarta Summit, President Soeharto of Indonesia set out on a journey to several capital cities in the West as well as to the General Assembly of the UN in New York in order to promote such a dialogue. On his return from New York he stopped over in Tokyo to discuss with the Japanese Government the possibility of his addressing the G-7 summit of July 1993 in order to explain in person the views and the new approach of the NAM with regard to the reactivation of the North-South dialogue.

When no immediate and positive reactions were forthcoming, Indonesia embarked on an active diplomatic campaign to seek further support for the NAM's plans. No diplomatic occasion was allowed to pass without persuading the leading Western countries to accept the proposals. The issue was therefore also raised during the visits to Indonesia of Prime minister Miyazawa of Japan, Chancellor Khol of Germany, and Foreign Secretary Hurd of Britain. Yet all these efforts seemed of little avail. It was later reported that while Germany, Japan and the US would be willing to receive Soeharto at the G-7 meeting in Tokyo, other members of the group were opposed to his presence. Instead Prime Minister Miyazawa was mandated by his colleagues to meet President Soeharto on their behalf. The two statesmen met before the opening of the G-7

87 For one assessment of the results of this Bali meeting, see supra Section 4 of this article (the New World Order).

88 "NAM Ministerial Meeting Agree(s) to Adopt Recommendations for Summit", Summit News, published by the Media Centre of the 10th Non-Aligned Summit, Jakarta, Indonesia, 1 September 1992, p. A-6. 
meeting giving Soeharto the opportunity to submit officially two messages outlining the non-aligned views on the nature and modalities of the desired dialogue. ${ }^{89}$

Regrettably, the final communique of the G-7 meeting makes no reference whatsoever to the approaches made by the NAM, nor does it mention the possibility of a new North-South dialogue. The communique did at least reflect some of the ideas and policies suggested in the course of President Soeharto's mission and it welcomed the initiatives taken by the developing countries to establish a more constructive partnership and dialogue on issues of mutual interest. ${ }^{90}$ One wonders what conclusions the NAM should draw from the fact that its new and "non-confrontative" approach produced so little positive reaction from the North.

\section{EVALUATION AND CONCLUSION}

The fact that NAM has outlived the Cold War has proved once again the strength of its major premise, namely that world peace is not served by the formation of huge military alliances, nor by States joining any rival groups in a Cold War confrontation. Rather world peace would be enhanced if States were to refrain from joining military alliances and instead pursue active and independent policies, while committing themselves to the search for ways to manage emerging world conflicts, or settle disputes peacefully.

In a world no longer affected by Cold War problems but still troubled by other types of tension and conflict, the developing world will have to deal with an unfamiliar, now unipolar international system, dominated by the West and heavily influenced by the USA. The Jakarta Summit has given the NAM an opportunity to adjust its position and speak out about some of the most vital and controversial issues of our time. It has offered its members guidance on how they might pursue their own foreign policies and yet remain within the general framework of the Movement's principles. However, an ever-changing international arena demands from the NAM constant alertness in order to review and re-adjust its policies whenever necessary.

The most striking result of the Jakarta Summit was the clear confirmation of support by the members for the NAM's objectives and principles, and the closing of ranks at a time when serious doubts were being expressed about its relevance and importance. This outcome renewed the Movement's dynamism

89 See "NAM to the G-7: An Invitation to Dialogue", South Letter, published by the South Centre, Geneva, No. 17 (Spring/Summer 1993), pp. 2-4.

90 Indonesian newspaper reports were also rather conflicting in their assessment of the results of the G-7 meeting for the NAM. Cf. "Falling Short in Tokyo," The Jakarta Post, 9 July 1993, p. 4/1" "G-7's Answer to NAM Leader," The Jakarta Post, 12 June 1993; "RI [Republic of Indonesia] Salutes G-7 for Dialog," The Jakarta Post, 16 July 1993, p.1/1. 
after years of relative inactivity, caused, in part, by the tragedy in Yugoslavia.

The Jakarta Summit also saw the return of Indonesia to the centre of the international political arena. Fully aware of the importance of the occasion for NAM as well as for itself, Indonesia spared neither expense nor effort to make a success of the conference. Everything possible was done to create the most favourable conditions for the delegates while great attention was paid to organizational matters.

The Jakarta Conference once again demonstrated that an international movement without permanent organs and permanent staff has to rely heavily on the resources, human as well as material, that the host nation can provide for the general running of its affairs both during and after the Summit meeting. President Soeharto was fully involved in all stages and aspects of the conference, personally chairing almost every session of the plenary and other meetings and yet finding time to have daily bilateral meetings with other heads of State or government. He also took it upon himself to follow up on some of the difficult assignments decided upon by the conference, not least the formidable task of trying to convince the G-7 countries that a new NorthSouth dialogue was not only necessary but also mutually beneficial.

For the task of organizing the summit as well as chairing the NAM for the next three years, Indonesia has made available some of her high-ranking officials. In his difficult task President Soeharto had the assistance of his dynamic and accessible minister of foreign affairs, Mr Ali Alatas. He made himself accessible to the national and foreign press. His frequent press conferences did a lot to make the general public, at home and abroad, more aware of the particular positions and policies pursued by the NAM. The significance of these efforts cannot be overstated, given the ignorance and misunderstanding which exist in the world at large about the NAM. Mr Alatas has recently been made chairman of a new NAM executive board which includes some of Indonesia's senior diplomats as well as one of its top economists. $^{91}$

For the all-important task of promoting the economic and social development of the Third World in the context of deteriorating world economic conditions, the NAM will have to mobilize all its available resources. This may be a long and arduous task. Mr Julius Nyerere, the present Director of the South Centre, in a sharply-worded speech before the conference, warned that the end of the Cold War and the possible emergence of a united North, may not entirely be in favour of the South. It might, he feared, increase the North's control over all aspects of Third World development. Nyerere therefore felt that the NAM should be expanded and strengthened and he called upon all the countries of the South to join the NAM in creating a real

91 "Top Economist Joins NAM Executive Board", The Jakarta Post, 14 September 1993, p. 2/4. 
"Movement of the South." of China into the Movement. It is true that China presently has only observer status, but in practice that has often been the first step towards full membership. For example Thailand, which, having joined the NAM as an observer at the Jakarta Summit, has now announced its application for full membership of the NAM. ${ }^{93}$

All this points to the importance of the North-South dialogue so earnestly sought by the NAM. It makes it very clear that the next three years will make great demands on the leadership qualities of Indonesia as the current NAM chairman. One may also be able to see whether the new, so-called "nonconfrontative" approach of the NAM towards North-South relations will bear fruit.

There is one more task for which the NAM seems to be eminently qualified under the changing conditions of the New International Order. During the East-West rivalry of the Cold War, each camp was constantly kept alert by ever-present criticism and comments from the opposing bloc, with the nonaligned countries making their views known occasionally when they felt that it was necessary to remind the superpowers of the greater interest of the world at large. Now that only one superpower remains, it is important that the NAM assumes the task of monitoring developments. Critical comments from the NAM could dissuade those whom a consciousness of power could tempt to pursue unnecessarily dangerous policies or lose sight of the rights and needs of the other nations of the world. In the past, the superpowers were not known for accepting criticism graciously, least of all from the developing countries. In the present situation, where power seems concentrated in one region, the NAM is the only independent element of some weight that can assume the task of criticism. ${ }^{94}$ If the NAM were to carry out this task in an objective, balanced and independent manner, it will strengthen its moral authority and enhance its role as the protector of the interests of the majority of humankind.

92 Statement by Julius NYRERE, op. cit. n. 68, p. 10.

93 "Thailand Applies to Join NAM", The Jakarta Post, 16 June 1993, p. 12/4.

94 Dr. MAHATHIR Mohamad, the Malaysian prime minister, who in the personal opinion of the present author showed himself in Jakarta to be a sharp but fair critic of certain Western policies, had to suffer rather rude and unfair criticism from members of the foreign press. Although Dr. MAHATHIR was perfectly able to cope with this, it is a clear sign of what critics who dare to challenge super-powers will have to expect. 